\title{
Protective effects of fermented ginseng on streptozotocin-induced pancreatic B-cell damage through inhibition of NF-kB
}

\author{
HAI-DAN YUAN ${ }^{1,2}$ and SUNG-HYUN CHUNG ${ }^{1}$ \\ ${ }^{1}$ Department of Life and Nanopharmaceutical Science, College of Pharmacy, \\ Kyung Hee University, Seoul 130-701, Korea; ${ }^{2}$ Department of Pharmaceutical analysis, \\ College of Pharmacy, Yanbian University, Yanji, Jilin Province 133000, P.R. China
}

Received May 22, 2009; Accepted July 2, 2009

DOI: 10.3892/ijmm_00000312

\begin{abstract}
Ginseng (Panax ginseng C.A. Meyer) is widely used in Asian countries as a traditional medicine for the treatment of various diseases. It is known to have anti-inflammatory effects, although the mechanism is not clear. In this study, preventive effects of fermented ginseng (FG) against streptozotocin (STZ)induced pancreatic $\beta$-cell death was assessed in RINm5F insulinoma cells. FG markedly inhibited the production of nitrite in a dose-dependent manner. The decrease in nitrite production was found to correlate with reduced inducible nitric oxide (iNOS) protein and mRNA levels. To characterize the anti-inflammatory mechanism of FG at the transcriptional level, we examined effects of FG on the activity of nuclear factor- $\kappa \mathrm{B}$ $(\mathrm{NF}-\kappa \mathrm{B})$. FG reduced a translocation of the NF- $\mathrm{NB}$ subunit and NF-кB-dependent transcriptional activity. FG blocked signaling upstream of NF- $\mathrm{\kappa B}$ activation, such as degradation of inhibitor factor- $\kappa \mathrm{B} \alpha(\mathrm{I} \kappa \mathrm{B} \alpha)$ and phosphorylations of extracellular signalregulated kinase (ERK) and c-Jun NH2-terminal kinase (JNK). These results suggest that FG protects against STZ-induced pancreatic $\beta$-cell damage by downregulation of iNOS, cyclooxygenase-2 (COX-2), and tumor necrosis factor- $\alpha$ (TNF- $\alpha$ ) gene expressions by blocking NF- $\mathrm{BB}$ and mitogen-activated protein kinase activities.
\end{abstract}

\section{Introduction}

Type 1 diabetes is an autoimmune disease, induced by selective destruction of insulin producing B-cells of the Langerhans islets (1). The mechanism underlying B-cell destruction is not clear (2). In the STZ-induced diabetic model, hyperglycemia arises from the irreversible destruction of pancreatic B-cells through free radicals and nitric oxide $(\mathrm{NO})$, causing degranulation

Correspondence to: Professor Sung Hyun Chung, College of Pharmacy, Kyung Hee University, 1 Hoegi-dong, Dongdaemun-ku, Seoul 130-701, Korea

E-mail: suchung@khu.ac.kr

Key words: fermented ginseng, nitric oxide, inducible nitric oxide synthase, cyclooxygenase- 2 , tumor necrosis factor- $\alpha$, nuclear factor- $-\mathrm{B}$, mitogen-activated protein kinases and reduction of insulin secretion (3). Many effects of STZ on pancreatic islets are similar to those exerted by interleukin- $1 \beta$ (IL-1ß) and some studies indicate that IL-1ß-induced islet injury as well as STZ-induced islet cytotoxicity are mediated by NO production $(4,5)$.

$\mathrm{NO}$ is a free radical messenger molecule that readily diffuses through plasma lemma to exert its biological activity in a variety of cells (6). Depending on the cell type, NO is produced in an enzymatic reaction catalyzed by one of the three isoforms of NO synthase (NOS): neuronal NOS (nNOS), endothelial NOS (eNOS), and inducible NOS (iNOS) (7). The third form of NOS, iNOS, is generally not present in resting cells, but is induced by various cytokines, such as IL-1ß, TNF- $\alpha$ and interferon- $\gamma($ IFN- $\gamma)(8,9)$. Similarly, it is now known that there are two distinct isoforms of cyclooxygenase (COX), COX-1 and COX-2. COX-2 is induced by several stimuli, and is responsible for the production of pro-inflammatory prostaglandins at the inflammatory site (10). A large amount of the pro-inflammatory mediator can stimulate many proteins and enzymes crucial to inflammatory reactions, such as the NF-kB and MAPKs pathways (11). Several studies have shown that mitogen-activated protein kinases (MAPKs) play critical roles for the activation of $\mathrm{NF}-\mathrm{\kappa B}$ and subsequently, regulate COX-2 as well as iNOS-NO expression $(12,13)$.

Ginseng (Panax ginseng C.A. Meyer) has been used for remedies in traditional Chinese medicine. Numerous studies demonstrate that ginseng improves the immune response in diabetic patients (14-16). To develop an anti-diabetic agent with better efficacy from ginseng radix, fermented ginseg (FG) was developed. Recently, FG was reported to possess hypoglycemic activity (17). In the present study, we investigated the protective effect of FG on STZ-induced B-cell dysfunction in the rat insulinoma cell line (RINm5F), and observed that FG prevented STZ-induced pancreatic $\beta$-cell damage, and suppressed iNOS, COX-2, and TNF- $\alpha$ gene expressions via downregulation of the MAPKs and inactivation of NF-кB.

\section{Materials and methods}

Antibodies and chemicals. Dulbecco's modified Eagle's medium (DMEM) and fetal bovine serum (FBS) were purchased from Gibco BRL (Grand Island, USA). Antibodies against ERK, phospho-ERK, JNK, phospho-JNK, ІкB $\alpha$, phospho-IкB $\alpha$, 
NF- $\kappa$ B oligonucleotide probe, iNOS, COX-2, and $\beta$-actin were from Santa Cruz Biotechnology (Santa Cruz, USA). Reverse transcriptase, Taq polymerase and MTS solution were supplied by Promega (Mannheim, Germany). The polyvinylidene difluoride blotting membrane was from Millipore (Massachusetts, USA) and ECL-reagent and protein and RNA extraction kits were from Intron Biotechnology Inc. (Beverly, USA). Other reagents were purchased from Sigma-Aldrich (St. Louis, USA) unless otherwise noted.

Preparation of FG. FG extract was obtained from ILHWA Co. Ltd. (Guri, Korea) which prepared the extract with its patented protocol. Briefly, the dried ginseng (1 kg) was extracted from 51 of ethanol and concentrated with a SpeedVac. Then the dry ginseng extract was incubated with an enzyme solution containing B-galactosidase (1.5\%, Sigma, USA) at $50^{\circ} \mathrm{C}$ for $72 \mathrm{~h}$ and the chilled solution was adjusted with citric acid to $\mathrm{pH}$ 5.6, and finally incubated the solution with cellulose (Sigma, USA) for $48 \mathrm{~h}$ at $37^{\circ} \mathrm{C}$ until diol ginsenoside peaks disappeared in UPLC chromatogram.

Analysis of ginsenosides in ginseng extracts. An Acquity liquid chromatograph (Waters, USA) equipped with gradient pump, autosampler, and diode array detection and an Acquity UPLC BEH C18 reversed-phase column (100x1.0 mm, i.d., $1.7 \mu \mathrm{m})$ were used. The mobile phase consisted of water (solvent A) and acetonitrile (solvent $\mathrm{B}$ ). The gradient elution was used as follows: $0-3 \mathrm{~min}, 5 \% \mathrm{~B} ; 10 \mathrm{~min}, 15 \% \mathrm{~B} ; 12 \mathrm{~min}, 30 \% \mathrm{~B} ; 15$ $\min , 35 \% \mathrm{~B} ; 20 \min 60 \% \mathrm{~B}$. The column temperature was kept constant at $35^{\circ} \mathrm{C}$ and the flow rate was $0.5 \mathrm{ml} / \mathrm{min}$.

Cell culture. Cells were purchased from the American Type Culture Collection. Rat islet insulinoma cell line was cultured in RPMI medium 1640 (Gibco BRL) containing 10\% FBS, $2 \mathrm{mM}$ L-glutamine, $100 \mathrm{U} / \mathrm{ml}$ penicillin/streptomycin, and $2.5 \mu \mathrm{g} / \mathrm{ml}$ of amphotericin $\mathrm{B}$ in a humidified atmosphere containing $5 \% \mathrm{CO}_{2}$ at $37^{\circ} \mathrm{C}$.

MTS cell proliferation assay. The cell viability was detected by MTS (3-(4, 5-dimethylthiazol-2-yl)-5-(3-carboxymethoxyphenyl)-2H-tetrazolium) assay in which cells were incubated with MTS solution and absorbance was recorded at $490 \mathrm{~nm}$. In the MTS assay, absorption is directly proportional to the number of viable cells. RINm5F cells seeded on 96-well plates at $1 \times 10^{5}$ cells/well were incubated and treated with indicated concentrations of FG for $24 \mathrm{~h}$. MTS reagent was then added and cells were incubated at $37^{\circ} \mathrm{C}$ for $1 \mathrm{~h}$. At the end of the incubation period, absorbance was recorded at $490 \mathrm{~nm}$ (Multiskan Ascent, Thermo Labsystems, Finland).

Nitrite measurement. Nitrite accumulation, an indicator of NO synthesis, was measured in the culture medium by Griess reagent. Briefly, $100 \mu 1$ of culture medium was mixed with $100 \mu 1$ of Griess reagent [equal volumes of $1 \%$ (w/v) naphtylethylenediamine- $\mathrm{HCl}$ ] and incubated at room temperature for $10 \mathrm{~min}$. The absorbance at $550 \mathrm{~nm}$ was then measured using a microplate reader. Fresh culture medium was used as a blank in all experiments. The amount of nitrite in the test samples was calculated from a sodium nitrite standard curve.
Western blot analysis. RINm5F cells ( $1 \times 10^{6}$ cells/dish) were pretreated with various concentrations of FG $(30,60,90 \mu \mathrm{g} / \mathrm{ml})$ for $3 \mathrm{~h}$, and then treated with STZ $(10 \mathrm{mM})$ for $24 \mathrm{~h}$. After $24 \mathrm{~h}$, cells were harvested, and total protein extracts were prepared using a protein extraction kit and insoluble protein was removed by centrifugation at 13,000 rpm for $15 \mathrm{~min}$. Supernatant was collected from the lysates and protein concentrations were determined using a Bio-Rad protein assay reagent according to the manufacturer's instruction. For Western blotting, $40 \mu \mathrm{g}$ of protein was separated by $8 \%$ SDS-polyacrylamide gel electrophoresis (SDS-PAGE) and transferred to polyvinylidene difluoride membranes in a transfer buffer consisting of $20 \mathrm{mM}$ Tris- $\mathrm{HCl}, 154 \mathrm{mM}$ glycine, and $20 \%$ methanol. The membranes were blocked with $5 \%$ skim milk in Tris-buffered saline with $0.1 \%$ Tween-20 (TTBS) and incubated with specific antibodies and revealed with horseradish-peroxidase-conjugated secondary antibodies. Protein bands were detected using an enhanced chemiluminescence Western blotting detection kit (Amersham) and then exposed to X-ray film.

RNA extraction and RT-PCR. Total RNA was isolated using an Easy-Blue total RNA extraction kit according to the manufacturer's instruction. Single-strand cDNA synthesis was performed as described previously (18), using $5 \mu \mathrm{g}$ of RNA, oligo-dT primers and reverse transcriptase in a total volume of $50 \mu \mathrm{l}$. PCR reactions were performed in a total volume of $20 \mu \mathrm{l}$ comprising $2 \mu \mathrm{l}$ of cDNA product, $0.2 \mathrm{mM}$ of each dNTP, 20 pmol of each primer and 1 unit of Taq polymerase. Oligonucleotide primer sequences used in PCR amplification were as follows, iNOS sense 5'-ATGGCTTGC CCCTGGAAFT-3', anti-sense 5'-GTACTTGGGATGCTCC ATGGTCA-3'; COX-2 sense 5'-ATGCTCTTCCGAGCTGT GCT-3', anti-sense 5'-TTACAGCTCAGTTGAACGCCT TTT-3'; TNF- $\alpha$ sense 5'-TACAGGCTTGTCACTCGAATT-3'; anti-sense 5'-ATGAGCACAGAAAGCATGATC-3'; CPN sense 5'-ATGGTCAACCCACCGTG-3', anti-sense 5'-TTAG AGTTGTCCACAGTTCGGAGA-3'. For iNOS, COX-2 and CPN, PCR was performed at $95^{\circ} \mathrm{C}$ for $5 \mathrm{~min}, 95^{\circ} \mathrm{C}$ for $30 \mathrm{sec}$, followed by $57^{\circ} \mathrm{C}$ for $30 \mathrm{sec}$, and $72^{\circ} \mathrm{C}$ for $30 \mathrm{sec}$, and amplified for 30 cycles. The RT-PCR products were electrophoresed on $1 \%$ agarose gels and visualized by $0.5 \mu \mathrm{g} / \mathrm{ml}$ ethidium bromide staining and scanning densitometry was performed with I-MAX Gel Image analysis system (Core-Bio, Seoul, Korea). CPN was amplified as a control gene.

Electrophoretic mobility shift assay (EMSA). RINm5F cells $\left(1 \times 10^{6}\right.$ cells/dish) were pretreated with various concentrations of FG $(30,60,90 \mu \mathrm{g} / \mathrm{ml})$ for $3 \mathrm{~h}$, and then $10 \mathrm{mM} \mathrm{STZ}$ was added to the culture media and after $4 \mathrm{~h}$, cells were harvested, and nuclear extract was prepared in nuclear extraction kit (Fermentas, Burlington, Canada). IкB $\alpha$ and $\mathrm{p}-\mathrm{I} \kappa \mathrm{B} \alpha$ in the cytoplasmic fractions were analyzed via Western blotting. Nuclear extract $(10 \mu \mathrm{g})$ was mixed with the double-stranded NF- $\kappa$ B oligonucleotide 5'-AGTTGAGGGGACTTTCC CAGGC-' 3 end-labeled by [ $\left.\gamma-{ }^{32} \mathrm{P}\right]$-dATP (underlying indicates a $\kappa \mathrm{B}$ consensus sequence or a binding site for $\mathrm{NF}-\kappa \mathrm{B} / \mathrm{cRel}$ homodimeric and heterodimeric complex). The binding reactions were performed at $37^{\circ} \mathrm{C}$ for $30 \mathrm{~min}$ in $30 \mu \mathrm{l}$ of reaction buffer containing $10 \mathrm{mM}$ Tris- $\mathrm{HCl}, \mathrm{pH} 7.5,100 \mathrm{mM}$ 
(A)

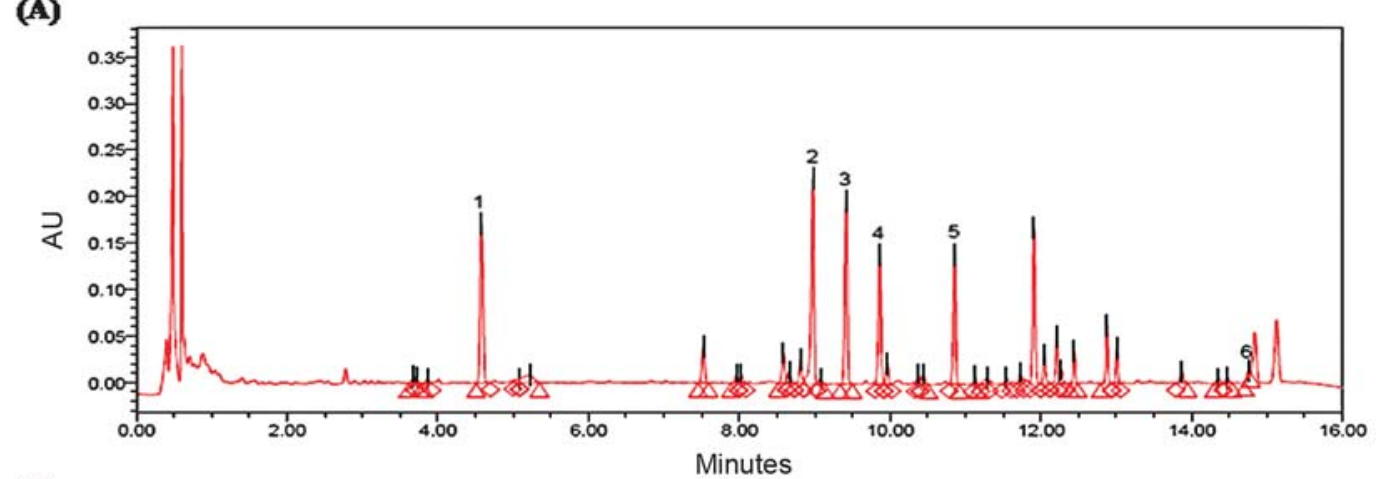

(B)

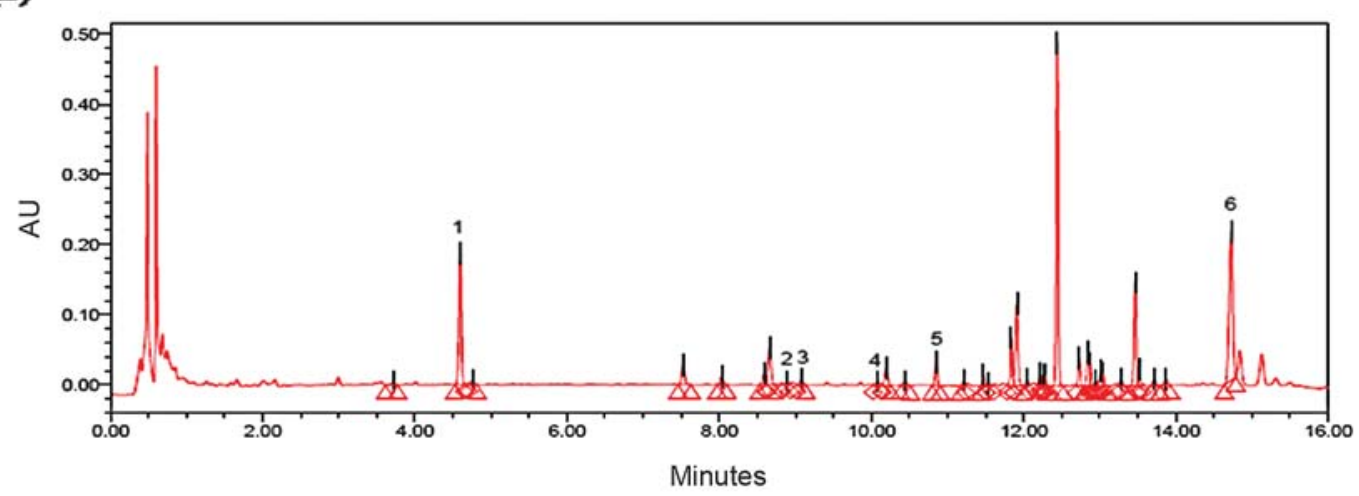

Figure 1. (A) UPLC profiles of ginseng radix and (B) fermented ginseng. 1, Rg1; 2, Rb1; 3, Rc; 4, Rb2; 5, Rd; 6, compound K.

$\mathrm{NaCl}, 1 \mathrm{mM}$ EDTA, $4 \%$ glycerol, $1 \mu \mathrm{g}$ of poly (dI-dC) and $1 \mathrm{mM}$ DTT. The specificity of binding was examined by competition with the 80-fold unlabeled oligonucleotide. DNA/nuclear protein complexes were separated from the unbound DNA probe on native $5 \%$ polyacrylamide gels at $100 \mathrm{~V}$ in $0.5 \mathrm{x}$ TBE buffer. The gels were vacuum dried for $1 \mathrm{~h}$ at $80^{\circ} \mathrm{C}$ and exposed to X-ray film at $-70^{\circ} \mathrm{C}$ for $24 \mathrm{~h}$.

Statistical analysis. Data are expressed as mean values \pm SD and comparisons of data were done by unpaired Student's t test. Mean values were considered significantly different when $\mathrm{p}<0.05$.

\section{Results}

UPLC analysis. UPLC chromatograms of untreated and $\beta$-galactosidase treated ginseng radix extracts are shown in Fig. 1. The saponin peaks in untreated ginseng radix, ginsenoside $\mathrm{Rb} 1, \mathrm{Rc}, \mathrm{Rb} 2$ and $\mathrm{Rd}$ were decreased during the enzyme treatment. After $72 \mathrm{~h}$ of $\beta$-galactosidase treatment, these four ginsenosides were difficult to identify in the chromatogram (Fig. 1B). On the other hand, compound K (peak 6) appeared during the enzyme process.

FG has no effect on the viability of RINm5F cells. To investigate whether FG affects the viability of RINm5F cells, a colorimetric proliferation assay was performed. FG did not affect cell viability at concentrations employed in this study (data not shown).

Effect of FG on cell proliferation. The potential protective effects of FG on cell survival in STZ-treated cells were evaluated. RINm5F cells were cultured to near confluence, then cells

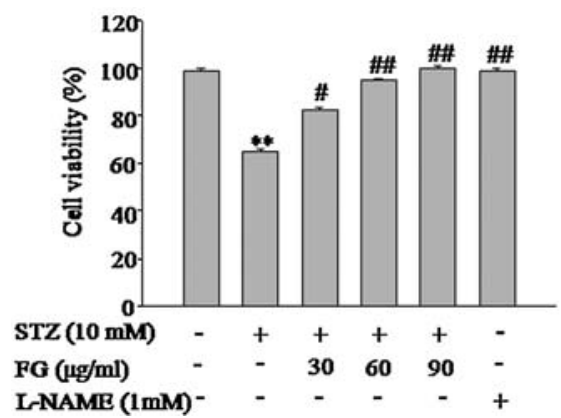

Figure 2. Prevention of STZ-induced cell death by FG. RINm5F cells $\left(1 \times 10^{5}\right)$ were pretreated with the indicated concentrations of FG or L-NANE $(1 \mathrm{mM})$ for $3 \mathrm{~h}$, and STZ $(10 \mathrm{mM})$ were added for $24 \mathrm{~h}$. The percentages of viable cells after treatment were determined by MTS assay. Each value is expressed as the mean $\pm \mathrm{SE}$ of three independent experiments. ${ }^{* *} \mathrm{p}<0.01$ vs. control; ${ }^{\#} \mathrm{p}<0.05,{ }^{\# \#} \mathrm{p}<0.01$ vs STZ.

were treated with FG $(30,60,90 \mu \mathrm{g} / \mathrm{ml})$ for $3 \mathrm{~h}$, prior to the addition of STZ (10 mM). After $24 \mathrm{~h}$, cell proliferation was determined by MTS assay. As shown in Fig. 2, STZ caused a significant reduction in cell viability to $64 \pm 1 \%$ when compared to control. FG restored the viability of STZ-treated RINm5F cells in a dose-dependent manner.

Effects of FG on nitrite production and iNOS expression. To assess the effect of FG on STZ-induced nitrite production in RINm5F cells, the cells were treated with STZ $(10 \mathrm{mM})$ for $24 \mathrm{~h}$ in the absence or presence of FG $(30,60,90 \mu \mathrm{g} / \mathrm{ml})$. The amount of nitrite, a stable metabolite of $\mathrm{NO}$, was determined as an indicator of NO production in the culture medium. STZ 
(A)

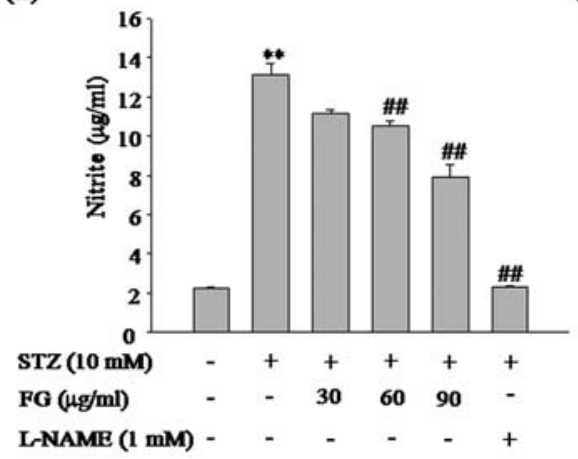

(B)

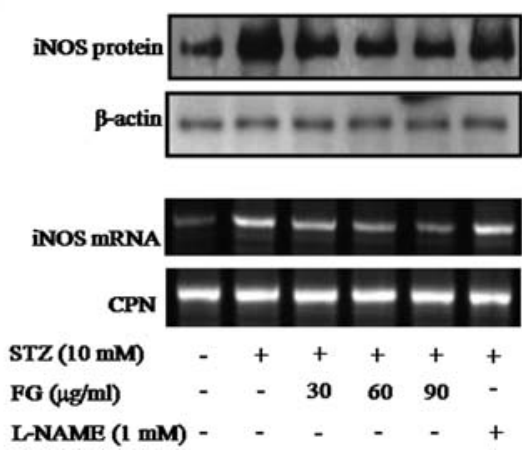

Figure 3. Effects of FG on STZ-induced NO production and iNOS expressions in RINm5F cells. (A) RINm5F cells (5x105) were pretreated with the indicated concentrations of FG or L-NAME $(1 \mathrm{mM})$ for $3 \mathrm{~h}$, and STZ $(10 \mathrm{mM})$ were added. After $24 \mathrm{~h}$ incubation, nitrite concentration was measured in the cell-free supernatants. (B) RINm5F cells $\left(1 \times 10^{6}\right)$ were cultured in 6-well plates and pretreated with the indicated concentrations of FG or L-NAME (1 mM) for $3 \mathrm{~h}$, after which STZ were added. Following $24 \mathrm{~h}$ incubation, iNOS protein and mRNA expression were analyzed by Western blotting and RT-PCR. Nitrite

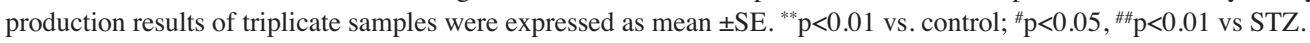

induced significant NO production compared to the naive control. The addition of $1 \mathrm{mM}$ N[omega]-nitro-L-arginine methylester (L-NAME), an iNOS inhibitor, completely prevented the production of NO (Fig. 3) and STZ-mediated cytotoxicity as expected (Fig. 2). Pretreatment with FG was found to significantly inhibit STZ-induced nitrite production in a dose-dependent manner (Fig. 3A). Cells treated with STZ markedly increased iNOS protein and mRNA expression, whereas cells treated with FG showed suppressed expression of iNOS in both protein and mRNA levels in a dose-dependent manner (Fig. 3B).

Effects of FG on COX-2 and TNF- $\alpha$ expression. Inhibition of COX-2 was shown to preserve $\beta$-cell function and increase basal insulin secretion. To evaluate the effect of FG on STZinduced expression of COX-2 genes in RINm5F cells, expressions of COX-2 protein and mRNA level were monitored by Western blot analysis and RT-PCR, respectively. As shown in Fig. 4, COX-2 protein and mRNA expressions were markedly increased in cells treated with STZ, whereas cells pretreated with FG showed suppressed expressions of the protein and mRNA level of COX-2. To further assess the potential protective effect of $\mathrm{FG}, \mathrm{TNF}-\alpha$ expression was also examined by RT-PCR. As shown in Fig. 4B, FG treatment inhibited TNF- $\alpha$ mRNA expression in a dose-dependent manner.

Effect of $F G$ on $N F-\kappa B$ activation. NF- $\mathrm{NB}$ is an important transcription factor that, together with its inhibitor ( participates in the activation of genes involved in immune responses (19). In order to elucidate the mechanism of FG, EMSA was performed to examine its effect on STZ-induced $\mathrm{NF}-\kappa \mathrm{B}$ activation. Treatment of RINm5F cells with STZ was found to increase NF- $\mathrm{NB}$ DNA binding, and pretreating cells with FG, reduced NF-кB DNA binding in a dose-dependent manner (Fig. 5A). NF- $\kappa$ B activation usually occurs after degradation of $\mathrm{I}_{\kappa} \mathrm{B} \alpha(20)$. To determine whether this $\mathrm{I}_{\kappa} \mathrm{B} \alpha$ degradation was related to I $\mathrm{B} \alpha$ phosphorylation, we examined the effect of FG on STZ-induced $\mathrm{p}-\mathrm{I} \kappa \mathrm{B} \alpha$ by Western blot analysis. The result showed that FG also reduced STZ-induced I $\mathrm{B} \alpha$ phosphorylation in a dose-dependent manner (Fig. 5B).

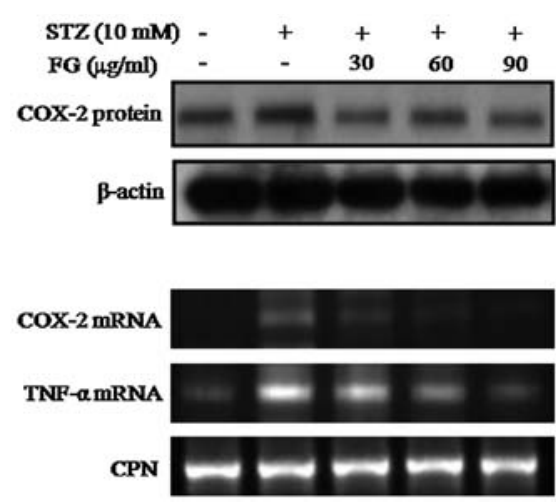

Figure 4. Effects of FG on STZ-induced COX-2 and TNF- $\alpha$ expressions in RINm5F cells. RINm5F cells $\left(1 \times 10^{6}\right)$ were cultured in 6-well plates and pretreated with the indicated concentrations of FG for $3 \mathrm{~h}$, and STZ (10 mM) were added. After $24 \mathrm{~h}$ incubation, COX-2 and TNF- $\alpha$ expression were measured by (A) Western blotting and (B) RT-PCR.

Effects of FG on ERK1/2 and JNK phosphorylation. To investigate whether the inhibition of NF- $\mathrm{BB}$ activation and $\mathrm{NO}$ production by FG is mediated through the MAPK pathway, we examined the effect of FG on STZ-induced phosphorylation of ERK1/2 and JNK by using Western blot analysis. Cells were pretreated with FG for $3 \mathrm{~h}$ and then treated with $10 \mathrm{mM} \mathrm{STZ}$ for $4 \mathrm{~h}$. As shown in Fig. 6, STZ-stimulated RINm5F cells had marked strong increases in the levels of phosphorylated ERK1/2 and JNK. However, pretreatment with FG significantly suppressed STZ-induced phosphorylations of ERK1/2 and JNK (Fig. 5).

\section{Discussion}

Medicinal plants have long been used for therapeutic purposes, and many of the currently available drugs are directly or indirectly derived from plants. Ginseng is a well known medical plant used in traditional oriental medicine for several thousand years. The pharmacological properties of ginseng are mainly attributed to ginsenosides, which are the active components found in the extracts of different species of ginseng. To develop an anti-diabetic agent with better efficacy from ginseng radix, 


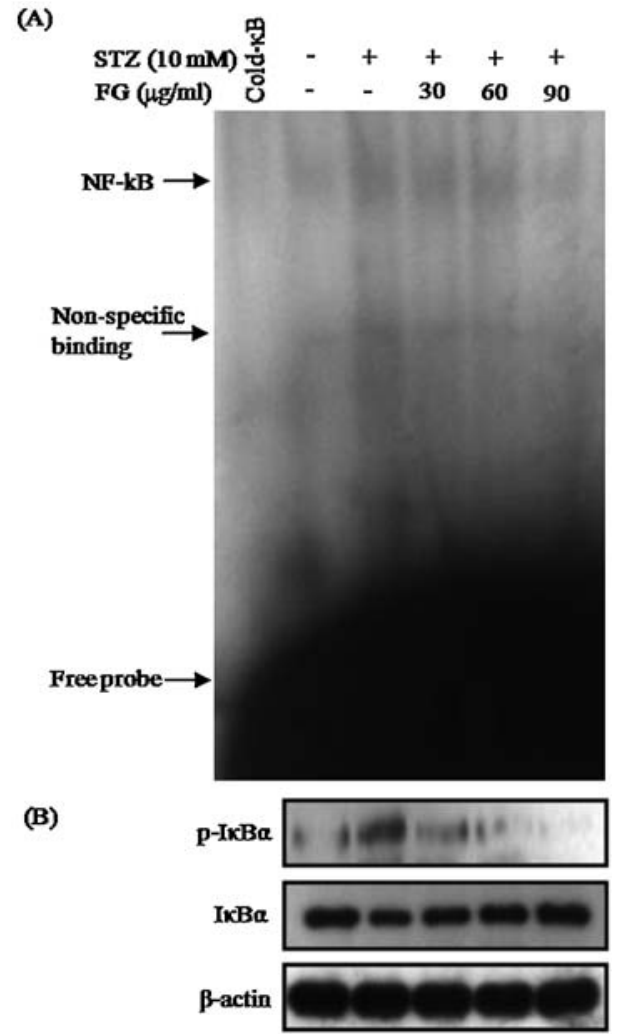

Figure 5. Effects of FG on the STZ-induced translocation of NF-kB from cytosol to the nucleus and IкB $\alpha$ degradation. RINm5F cells $\left(1 \times 10^{6}\right)$ were cultured in 6-well plates and pretreated with the indicated concentrations of FG for $3 \mathrm{~h}$, and STZ $(10 \mathrm{mM})$ were added. After $4 \mathrm{~h}$ incubation, NF-кB translocation was analyzed by the electrophoretic mobility shift assay. Protein levels of $\mathrm{p}$-IкB $\alpha, \mathrm{I} \kappa \mathrm{B} \alpha$ in the cytosolic extract were determined by Western blotting.

ginseng ethanol extract was treated with B-glucosidase to enrich compound K (Fig. 1). Recently, ginsenosides, Rb1, Rg1, Rg3, $\mathrm{Rh} 2, \mathrm{Re}$, compound $\mathrm{K}$ have been widely documented in many studies and shown to have anti-oxidative, anti-inflammatory and anti-proliferative effects $(21,22)$. However, the active component responsible for anti-inflammatory activity in the pancreatic B-cell has yet to be identified.

In the present study, we demonstrated that FG has a protective effect against STZ-induced B-cell death in RINm5F cells. Whereas STZ induced nitrite generation in pancreas ß-cells, was attenuated by FG. Much evidence supports the hypothesis that high-output NO by iNOS provokes deleterious consequences in inflammatory diseases $(3-5,23)$. The ability of FG to attenuate STZ-induced $\beta$-cell damage was demonstrated by modulating the activity of immune response.

NO is a short-lived and highly reactive radical (24). Besides its direct toxicity, NO reacts with superoxide to form peroxynitrite, which has much stronger oxidant activity and mediates B-cell destruction in type 1 diabetes (25). Many studies documented that the iNOS inhibitor L-NAME attenuates cytokine-induced $\beta$-cell dysfunction and islet degeneration (24-26). In our experiment, L-NAME prevented STZ-induced NO production and $\beta$-cell dysfunction. Pretreatment with FG was found to significantly inhibit STZ-induced NO production in a dose-dependent manner (Fig. 3A). This result suggests that the protective effect of FG against STZ-induced B-cell damage is due to the inhibition of nitrite production.

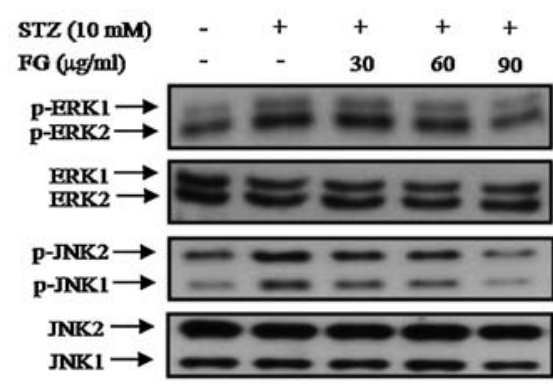

Figure 6. Effects of FG on STZ-induced phosphorylations of MAPKs in Rinm5F cells. RINm5F cells $\left(1 \times 10^{6}\right)$ were cultured in 6 -well plates and pretreated with the indicated concentrations of FG for $3 \mathrm{~h}$, and STZ $(10 \mathrm{mM})$ were added. After $4 \mathrm{~h}$ incubation, the whole cell lysates were analyzed by immunoblot analysis using various antibodies against the activated MAPKs.

$\mathrm{NO}$ is regulated mainly by the transcriptional factor NF-кB (26). NF-кB regulates the expressions of multiple proinflammatory genes that contribute to $\beta$-cell destruction such as iNOS, COX-2 and TNF- $\alpha(27,28)$. Therefore, we examined the DNA-binding activity of p65 to confirm the inhibition of the expressions of iNOS, COX-2 and TNF- $\alpha$ (Figs. 3B and 4). Our results suggested that DNA binding activity of p65 is inhibited in a dose-dependent manner by FG (Fig. 5A). In unstimulated cells, NF- $\mathrm{NB}$ is located in the cytosol as an inactive complex bound to IкB; this complex is phosphorylated, subsequently degraded and then dissociates to activate NF-кB (29). In this study, our results demonstrate that FG prevented STZ-induced degradation and resynthesis of IкB $\alpha$ protein (Fig. 5B). Therefore, these results suggest that FG inhibits STZ-induced expressions of iNOS, COX-2 and TNF- $\alpha$ and thus inhibit NO production through inactivation of NF- $\mathrm{KB}$ by reducing $\mathrm{I} \kappa \mathrm{B} \alpha$ phosphorylation and degradation.

One of the most extensively investigated intracellular signaling cascades involved in pro-inflammatory responses is the MAPK pathway. The MAPK pathway is important for the activation of $N F-\kappa B(11-13)$. To further investigate the molecular mechanism underlying NF- $\mathrm{KB}$ inactivation and $\mathrm{NO}$ inhibition by FG, protective effects of FG on STZ-induced phosphorylation of ERK1/2 and JNK were examined by Western blot analysis. The data demonstrated that FG significantly inhibited the phosphorylation of ERK $1 / 2$ and JNK (Fig. 6). This result suggests that the mechanism by which pretreatment with FG inhibits STZ-induced NF-кB activation is due to the downregulation of the phosphorylation of ERK $1 / 2$ and JNK.

In summary, our results suggest that FG prevented STZinduced pancreas $B$-cell damage and inhibited NO production in STZ-induced RINm5F through suppression of iNOS, COX-2 and TNF- $\alpha$ expression via downregulation of the MAPK signal pathway and inactivation of NF- $\mathrm{KB}$. These data indicate that FG has a beneficial effect when used to prevent the progress of type 1 diabetes.

\section{Acknowledgements}

This work was supported by a grant from the Kyung Hee University post-doctoral fellowship in 2009 (20090504). 


\section{References}

1. Amirshahrokhi K, Dehpour AR, Hadjati J, Sotoudeh M and Ghazi-Khansari M: Methadone ameliorates multiple-low-dose streptozotocin-induced type 1 diabetes in mice. Toxicol Appl Pharmacol 232: 119-124, 2008.

2. Pirot P, Cardozo AK and Eizirik DL: Mediators and mechanisms of pancreatic beta-cell death in type 1 diabetes. Arq Bras Endocrinol Metabol 52: 156-165, 2008.

3. Zhang Y, Cai J, Ruan H, Pi H and Wu J: Antihyperglycemic activity of kinsenoside, a high yielding constituent from Anoectochilus roxburghii in streptozotocin diabetic rats. J Ethnopharmacol 114: 141-145, 2007

4. Corbett JA, Wang JL, Misko TP, Zhao W, Hickey WF and McDaniel ML: Nitric oxide mediates IL-1 beta-induced islet dysfunction and destruction: prevention by dexamethasone. Autoimmunity 15: 145-153, 1993.

5. Kwon NS, Lee SH, Choi CS, Kho T and Lee HS: Nitric oxide generation from streptozotocin. FASEB J 8: 529-533, 1994.

6. Yang F, Troncy E, Francceur M, Vinet B, Vinay P and Czaika G: Effects of reducing reagents and temperature on conversion of nitrite and nitrate to nitric oxide and detection of NO by chemiluminescence. Clin Chem 43: 657-662, 1997.

7. Moshage H: Nitric oxide determination: much ado about NOthing? Clin Chem 43: 553-556, 1997.

8. Darville MI and Eizirik DL: Regulation by cytokines of the inducible nitric oxide synthase promoter in insulin-producing cells. Diabetologia 41: 1101-1108, 1998.

9. Rabinovitch A and Suarez-Pinzon WL: Cytokines and their roles in pancreatic islet beta-cell destruction and insulin-dependent diabetes mellitus. Biochem Pharmacol 55: 1139-1149, 1998.

10. Altorki NK, Subbaramaiah K and Dannenberg AJ: Cyclooxygenase-2: a target for the prevention and treatment of cancers of the upper digestive tract. Prog Exp Tumor Res 37: 107-123, 2003.

11. Mokhtari D, Myers JW and Welsh N: MAPK kinase kinase-1 is essential for cytokine-induced c-Jun NH2-terminal kinase and nuclear factor-kappaB activation in human pancreatic islet cells. Diabetes 57: 1896-1904, 2008.

12. Kim JH, Na HK, Pak YK, Lee YS, Lee SJ, Moon A and Surh YJ: Roles of ERK and p38 mitogen-activated protein kinases in phorbol ester-induced NF-kappaB activation and COX-2 expression in human breast epithelial cells. Chem Biol Interact 171: 133-141, 2007.

13. Pan MH, Lai CS, Wang YJ and Ho CT: Acacetin suppressed LPS-induced up-expression of iNOS and COX-2 in murine macrophages and TPA-induced tumor promotion in mice. Biochem Pharmacol 72: 1293-1303, 2006.

14. Wu Z, Luo JZ and Luo L: American ginseng modulates pancreatic beta cell activities. Chin Med 25: 2-11, 2007.

15. Kiefer D and Pantuso T: Panax ginseng. Am Fam Physician 68: 1539-1542, 2003.

16. Yin J, Zhang H and Ye J: Traditional Chinese medicine in treatment of metabolic syndrome. Endocr Metab Immune Disord Drug Targets 8: 99-111, 2008.
17. Kim DY, Park JS, Yuan HD and Chung SH: Fermented ginseng attenuates hepatic lipid accumulation and hyperglycemia through AMPK activation. Food Sci Biotechnol (In press).

18. Akli S, Chelly J, Lacorte JM, Poenaru L and Kahn A: Seven novel Tay-Sachs mutations detected by chemical mismatch cleavage of PCR-amplified cDNA fragments. Genomics 11: 124-134, 1991.

19. Romzova M, Hohenadel D, Kolostova K, Pinterova D Fojtikova M, Ruzickova S, Dostal C, Bosak V, Rychlik I and Cerna M: NFkappaB and its inhibitor IkappaB in relation to type 2 diabetes and its microvascular and atherosclerotic complications. Hum Immunol 67: 706-713, 2006.

20. DiDonato JA, Mercurio F and Karin M: Phosphorylation of Ikappa B alpha precedes but is not sufficient for its dissociation from NF-kappa B. Mol Cell Biol 15: 1302-1311, 1995.

21. Seo JY, Lee JH, Kim NW, Her E, Chang SH, Ko NY, Yoo HY, Kim JW, Seo DW, Han JW, Kim YM and Choi WS: Effect of fermented ginseng extract, BST204, on the expression of cyclooxygenase- 2 in murine machropharges. Int Immunopharmacol 5: 929-936, 2005.

22. Cho WC, Chung WS, Lee SK, Leung AW, Cheng $\mathrm{CH}$ and Yue KK: Ginsenoside Re of Panax ginseng possesses significant antioxidant and antihyperlipidemic efficacies in streptozotocininduced diabetic rats. Eur J Pharmacol 550: 173-179, 2006.

23. Zamora R, Vodovotz Y and Billiar TR: Inducible nitric oxide synthase and inflammatory diseases. Mol Med 6: 347-373, 2000.

24. Kim EK, Kwon KB, Song MY, Seo SW, Park SJ, Ka SO, Na L, Kim KA, Ryu DG, So HS, Park R, Park JW and Park BH: Genistein protects pancreatic beta cells against cytokinemediated toxicity. Mol Cell Endocrinol 278: 18-28, 2007.

25. Matsuda T, Ferreri K, Todorov I, Kuroda Y, Smith CV, Kandeel F and Mullen Y: Silymarin protects pancreatic beta-cells against cytokine-mediated toxicity: implication of c-Jun NH2-terminal kinase and janus kinase/signal transducer and activator of transcription pathways. Endocrinology 146: 175-185, 2005.

26. Kim EK, Kwon KB, Song MY, Han MJ, Lee JH, Lee YR, Lee JH, Ryu DG, Park BH and Park JW: Flavonoids protect against cytokine-induced pancreatic beta-cell damage through suppression of nuclear factor kappaB activation. Pancreas 35: E1-E9, 2007

27. Kim S, Millet I, Kim HS, Kim JY, Han MS, Lee MK, Kim KW, Sherwin RS, Karin M and Lee MS: NF-kappa B prevents beta cell death and autoimmune diabetes in NOD mice. Proc Natl Acad Sci USA 104: 1913-1918, 2007

28. Kwon G, Corbett JA, Hauser S, Hill JR, Turk J and McDaniel ML: Evidence for involvement of the proteasome complex (26S) and NFkappaB in IL-1beta-induced nitric oxide and prostaglandin production by rat islets and RINm5F cells. Diabetes 47: 583-591, 1998.

29. Rodriguez MS, Thompson J, Hay RT and Dargemont C: Nuclear retention of IkappaBalpha protects it from signalinduced degradation and inhibits nuclear factor kappaB transcriptional activation. J Biol Chem 274: 9108-9115, 1999. 